\title{
Food sovereignty and agricultural land use planning: The need to integrate public priorities across jurisdictions
}

\author{
David J. Connell, ${ }^{\mathrm{a} * *}$ Christopher R. Bryant, ${ }^{\mathrm{b}}$ Wayne J. Caldwell, ${ }^{\mathrm{c}}$ Arthur Churchyard, ${ }^{\mathrm{d}}$ \\ Greg Cameron, ${ }^{\mathrm{e}}$ Tom Johnston, ${ }^{\mathrm{f}}$ Matias E. Margulis, ${ }^{\mathrm{g}}$ Doug Ramsey, ${ }^{\mathrm{h}}$ and Claude Marois ${ }^{\mathrm{i}}$
}

Submitted June 9, 2013 / Revised August 8, 2013 / Published online August 26, 2013

Citation: Connell, D. J., Bryant, C. R., Caldwell, W. J., Churchyard, A., Cameron, G., Johnston, T., Margulis, M. E., Ramsey, D., \& Marois, C. (2013). Food sovereignty and agricultural land use planning: The need to integrate public priorities across jurisdictions. Journal of Agriculture, Food Systems, and Community Development, 3(4), 117-124. http://dx.doi.org/10.5304/jafscd.2013.034.011

Copyright (C) 2013 by New Leaf Associates, Inc.

\begin{abstract}
Recent calls for national food policies that promote greater food sovereignty represent an emerging concern of public policy. Such a shift in food policy toward greater citizen control over domestic

* Corresponding author.

a Associate Professor, School of Environmental Planning, University of Northern British Columbia, 3333 University Way, Prince George, British Columbia, V2N 4Z9 Canada; +1250-960-5835; david.connell@unbc.ca

b Professor, Geography, Université de Montréal, 2900

Boulevard Edouard-Montpetit, Montreal, Quebec, H3C 3A8

Canada; chris.r.bryant@,umontreal.ca

c Professor, School of Environmental Design and Rural Development, University of Guelph, 50 Stone Road East, Guelph, Ontario, N1G 2W1 Canada; wcaldwel@uoguelph.ca

d Independent researcher; arthur.churchyard@gmail.com

e Associate Professor, Faculty of Agriculture, Dalhousie University, 62 Cumming Drive, Truro, Nova Scotia, B2N 5E3

Canada; gregory.cameron@,dal.ca
\end{abstract}

food supplies would have significant implications for all aspects of the agri-food system. One area of concern is the conservation and use of agricultural land because, in the end, every act of producing and consuming food has direct or indirect impacts on the land base. Yet no research has considered the potential interactions and implications between food sovereignty and agricultural land use planning.

${ }^{\mathrm{f}}$ Associate Professor, Geography, University of Lethbridge, 4401 University Drive West, Lethbridge, Alberta, T1K 3M4 Canada; johnston@uleth.ca

g Assistant Professor, International Studies, University of Northern British Columbia, 3333 University Way, Prince George, British Columbia, V2N 4Z9 Canada; matias.margulis@unbc.ca

h Associate Professor, Rural Development, Brandon University, 270 18th St., Brandon, Manitoba, R7A 6A9 Canada; ramsey@brandonu.ca

i Professor, Geography, Université de Montréal, 2900 Boulevard Edouard-Montpetit, Montreal, Quebec, H3C 3A8 Canada; claude.marois@umontreal.ca 
This gap in research presents an opportunity to critically examine the effects of the changing roles and values on agricultural land use planning within and across jurisdictions. We believe that a better understanding of the dominant policy regimes within the agri-food system, including global competitiveness, farmland preservation, and food sovereignty, can lead to land use planning practices that are most beneficial for integrating not only multiple interests across jurisdictions, but also multiple perspectives.

\section{Keywords}

agricultural land use planning, farmland conservation, food sovereignty, global competitiveness, planning theory, policy regime analysis

$\mathrm{T}$ he purpose of this commentary is to focus on the need for researchers to critically examine how the changing role and value of food and agriculture, as reflected in recent calls for national food policies that promote greater food sovereignty, affect agricultural land use planning within and across jurisdictions. While the commentary focuses on Canada, the aim is to discuss land use policy and legislative issues that are relevant, to greater or lesser degrees, throughout North America.

The recent emergence of food sovereignty as a subject of national policy reflects growing public concerns about the security and safety of the domestic food supply. It also reflects concerns about the right of peoples to define, protect, and regulate domestic agricultural production and land policies that promote safe, healthy, and ecologically sustainable food production that is culturally appropriate (International Planning Committee for Food Sovereignty, 2002). In Canada there have been several recent calls for citizens to have greater control over national agri-food policies (Qualman, 2011; Wiebe \& Wipf, 2011; Wittman, Desmarais, \& Wiebe, 2010, 2011). The National Farmers Union (NFU, 2010), Canadian Federation of Agriculture (CFA, 2010) and Food Secure Canada (2011) are some of the national actors calling for changes. The NFU, for example, argues that, "Farmer autonomy and control are fast eroding. As farmers lose that control, they lose the ability to make effective long-term plans. And Canadians lose sovereignty over their territory and their food systems" (NFU, 2010, p. 22). Adopting policies that promote greater food sovereignty could easily reach into people's daily lives, with economic, social, and environmental implications. Such a shift in food policy would also have significant implications for the conservation and use of agricultural land because, in the end, every act of producing and consuming food has direct or indirect impacts on the land base. Yet no research has considered the potential interactions and implications between food sovereignty and agricultural land use planning.

One approach to examining this relationship is to combine the theoretical frameworks of policy regime analysis and planning. To understand how policy regimes change or reinforce the status quo, Jochim and May (2010) argue that the formation and change of policy regimes can be examined by focusing on four key domains: issues, ideas, interests, and institutions. With this approach one can evaluate the emergence, strength, and durability of a policy regime in conjunction with a thorough analysis of relevant strategy documents and debates to assess the uptake of ideas, levels of support, and capacity to coordinate governing institutions to structure authority, attention, and information flows. For example, the recent calls for change to national agri-food policies have the potential to shape institutional development and to mobilize concerned interests not only across policy boundaries (horizontal) but also across jurisdictions, from national to local (vertical). Howlett, Ramesh, $\&$ Perl $(2009$, p. 2) state that we must look to the policy actors to determine the content and process of public policy-making, and also explore the structures and institutions that serve to constrain and influence those actors' efforts. In his study of farm and food policy in Canada, Forbes (1985) notes the need to infer specific inputs by observing outcomes because of the secret or not publicly reported details of policy-making decisions.

Food sovereignty is an example of what Jochim and May (2010) describe as a "messy policy problem" (p. 304). Jochim and May are referring to boundary-spanning policy regimes "that foster integrative actions across elements of multiple sub- 
systems," and in so doing create greater challenges for formulating policy and for governing once policies are devised. What makes an examination of food sovereignty as a policy even messier is its interactions with and implications for other longstanding policy regimes such as global competitiveness and farmland conservation.

A policy regime of global competitiveness has strengthened over the past 40 years at both the national and provincial levels (Ash \& Brink, 1994; Barichello, 1995; Bryant, 2012; Dakers, 1996; Miner, 1994). Dakers and Forge (2000) describe this policy objective as ensuring the "industry's viability in a context of freer trade" (Evolving Departmental Structure section, para. 1). Several other authors (Ash \& Brink, 1994; Miner, 1994; Wilson, 1990) describe a similar trend while highlighting strategies to successfully integrate the domestic agricultural sector into the global economy. A recent report on competitiveness by the House of Commons Standing Committee on Agriculture and Agri-Food (2010) focused on access to new markets, barriers to trade, food safety, product labeling, and market concentration within sectors. Input to this report was provided by national and regional commodity trade associations, meat and other food processors, transportation associations, and policy institutes, among others. Although the membership of the agri-food policy community in Canada is strong individually, the community is nationally fragmented and organizationally divided, as national policies do not always serve all members or geographic regions equally (Skogstad, 1990). For example, exportoriented policies may promote the export of raw food products at the risk of higher prices for domestic food processors. Such policies also have regional differences, where policies may benefit one region (food processing in central Canada) to the disadvantage of food producers in another region (food producers in the prairies). Notwithstanding these internal challenges, the competitiveness policy regime continues to strengthen, as evident in the Growing Forward 2 policy framework announced on September 14, 2012 (Agriculture and Agri-Food Canada [AAFC], 2012).

Conserving farmland first garnered serious public attention in the early 1970s with most provincial and local jurisdictions having some form of legislation or guidelines in place by the end of the 1970s (Beesley \& Ramsey, 2009; Bunce, 1998; Furuseth \& Pierce, 1982a, 1982b). Caldwell, Hilts, $\&$ Wilton (2007a) provide a comprehensive account of farmland conservation policies in and across Canada (see also Bray, 1980; Caldwell, 1995; Caldwell \& Dodds-Weir, 2009; Johnston \& Smit, 1985). Their text reviews the historical development of farmland policies in Québec (Bryant \& Granjon, 2007; also Bryant, 2011; Bryant, Singh, \& André, 2007), Ontario (Caldwell, Hilts, \& Wilton, 2007b; see also Caldwell \& Hilts, 2005; Gayler, 2003, 2004, 2005, 2010), and British Columbia (Smith, 2007; also Smith, 1998). These policies were accompanied by an "array of economic, environmental, and social conflicts [which] characterize the tension between urban, recreational, infrastructure, and industrial land uses, and viable rural or agricultural communities" (Hiley, 2007, p. 163). Correspondingly, motivations for conserving farmland are influenced by factors such as food production, market value for land, environmental issues, amenity of rural landscapes, agrarian ideals, and land use conflicts on the urban fringe (Wilton, 2007). In spite of efforts over the past 40 years, Canada has experienced a continual loss of prime farmland across the country. Hoffman (2001) observed, for example, that since 1971 urban activities have been responsible for the conversion of $12,000 \mathrm{sq} . \mathrm{km}$. (4,633 sq. miles) of farmland, one-half of which was classified as prime agricultural land under the Canada Land Inventory. The issue is especially acute in Ontario, which contains the country's largest supply of prime agricultural lands (Simpson-Lewis, Moore, Pocock, Taylor, \&Swan, 1979), but has been documented elsewhere, including Alberta (Alberta Agriculture, Food and Rural Development, Resource Planning Group, 2002) and British Columbia (CavendishPalmer, 2008).

At some point the mixed messages and crossimplications of agri-food policy regimes must be reconciled through how we choose to use our finite land base. The core concern of planning in the public domain, according to Friedmann (2003; also Allmendinger, 2009), is how knowledge should be properly linked to action and specifically, as 
Connell $(2009,2010)$ explains, to society's need to actively construct a desirable future. The function of land use planning is to make future public and private interests in the types, amounts, and spatial arrangements of desired land uses a visible part of present decision-making processes (Connell, 2009), and must consider the public's interests in environmental quality, land conservation, health, economic efficiency, social equity, heritage, infrastructure, transportation, and affordability, to name a few (Leung, 2003). The desired outcome of the planning process is to identify and reconcile the relevant interests that often compete with each other for access to and use of the same land base.

Across North America, the historical decline in the economic and social role of agriculture has been accompanied by a significant reduction in and degradation of the prime agricultural land base. This land base faces growing pressures from urban development and the pursuit of other economic priorities, with few indications that this trend will be significantly curtailed (e.g., Benjamin, 2011). As well, the rights and capacities of farmers to use agricultural lands are increasingly compromised by neighboring nonfarm uses, such as when residential neighbors file unwarranted nuisance complaints about farm odors and noise, or sever (subdivide) residential building lots near agricultural operations (Caldwell, Churchyard, Dodds-Weir, Eckert, \& Procter, 2011). Consequently, the nationally significant yet localized nature of agricultural land use issues points to the need for coordination among multiple jurisdictions. The issues, however, are complicated as difficulties of cohabitation are not just related to scale (the proximity of farm and nonfarm uses) but can also be related to differences in cultural values and also to how land and activities (farm and nonfarm) are managed. Land protection alone is not adequate over the long term; better management processes are needed to complement land use planning per se. This means being able to accompany farmers in the development of their activities (by counseling, providing useful information, and facilitating) and helping nonfarm people integrate better into the rural community.

Reconciling competing interests for agricultural lands remains a complicated process that crosses multiple jurisdictions. Under Canada's Constitution Act, the federal and provincial governments share responsibility for agriculture. Local interest is the result of the provinces delegating certain areas of decision-making to the local level, with varying degrees of provincial oversight. (This makes Canada's legislative framework different from the home rule of the United States.) Domestic agricultural policy is also highly influenced by international relations and agricultural policies (e.g., Agriculture Agreement as part of the World Trade Organization's Uruguay Round), as most countries function in an increasingly globalized economy (Skogstad, 1990, 2012; Wilson 1990). This point is well illustrated by the attention Canada's supply-managed sectors have attracted in various trade discussions (e.g., NAFTA and the Trans-Pacific Partnership). Similar debates have taken place in the European Union, leading to policies based on "multifunctionality," in which economic, environmental, and social goals beyond the production of food and fiber are embedded in agri-food policy, as reflected in recent reforms to Europe's Common Agricultural Policy (Skogstad, 2012; also Moyer \& Josling, 2002; Ritson \& Harvey, 1997; see Blay-Palmer (2012) for a discussion of adopting multifunctional policy in Canada).

The agri-food policy regimes of global competitiveness and farmland preservation will continue to be influenced profoundly by development and adaptation to shifting domestic and global drivers, including market volatility, urbanization, climatic disruptions to global food supplies, and growing demand for local food and farmland amenities. The addition of food sovereignty to the mix complicates the situation by introducing new voices with greater potential for conflicting interests over land uses, all of which add to the changing role and value of food and agriculture in North American society. From a research perspective, we believe there are three critical areas that can be pursued to examine critically the effects of these changing roles and values on agricultural land use planning within and across jurisdictions. 
Research objective: Document and analyze the dominant policy regimes within the agriculture and agri-food system, including global competitiveness, farmland preservation, and food sovereignty. Related objectives are:

(a) To understand the structure and dynamics of the agri-food policy system, including issues, ideas, interests, and institutions of each agricultural policy regime; emergence, strength, and compatibility of agricultural policy regimes; and ideologies, issues, and intentions of key stakeholders;

(b) To document each agricultural policy regime at national, provincial/state, and local levels, including guidelines, programs, plans, and strategies; and

(c) To assess the potential impacts of implementing a food sovereignty regime on farmland conservation and the rights to farm.

Research objective: Undertake studies of agricultural land use planning processes at the level of local governments in different regions. The studies could be guided by three research questions:

(a) To what extent do existing agricultural land use plans, which are generally integrated into or part of broader land use plans, accommodate the dominant policy regimes?

(b) To what extent do existing agricultural land use plans integrate policy across all levels of government?

(c) What practices are most beneficial among these agricultural land use plans, strategies, and policies, including proactive management processes? For example, how have they integrated not only policy across jurisdictions but also multiple perspectives such as those of citizens, local organizations, professional organizations representing farmers, and environmental groups?

Research objective: Mobilize and apply the knowledge generated by researchers to help formulate more integrated agricultural land use planning solutions in rural, peri-urban, and urban areas.

(a) Provide an evidence-based perspective on public policy for agriculture and food;

(b) Host regional workshops focused on integrated solutions to agricultural land-use planning; and

(c) Host a forum of national stakeholders focused on formulating policy recommendations for agricultural land use planning.

We believe that pursuing these questions can contribute to three scholarly foundations of food systems research and community development: agricultural planning and farmland conservation; food sovereignty, food security, and local food movements; and policy studies. Overall, although the relevant literature provides a comprehensive foundation for the study of agricultural land use planning, food sovereignty represents a nascent policy regime that could have profound impacts on domestic agricultural policies across all levels of jurisdiction. Through the objectives we have identified, researchers can help provide an evidence-based perspective to the current public debate and clearly delineate food sovereignty considerations from the perspective of global competitiveness and farmland conservation. The extent to which current debates may or may not alter the trajectory of domestic policies will be of benefit to land use decision makers, planning practitioners and policy-makers at all levels of government, to nongovernmental organizations, industry groups, farmer organizations, farmers, and the general public, as well as to other jurisdictions around the world dealing with similar agri-food issues.

\section{References}

Agriculture and Agri-Food Canada [AAFC]. (2012, September 14). New Growing Forward agreement will drive innovation, market development and long-term growth in Canadian agriculture [Media release]. Retrieved from http://www.agr.gc.ca/cb/ index e.php?s1 $=$ n\&s2 $=2012$ \&page $=$ n120914 
Alberta Agriculture, Food and Rural Development, Resource Planning Group. (2002). Loss and fragmentation of farmland. Edmonton: Government of Alberta.

Allmendinger, P. (2009). Planning Theory (Second ed.). New York: Palgrave.

Ash, K., \& Brink, L. (1994). Assessing the role of competitiveness in shaping policy choices: A Canadian perspective. In M. E. Bredahl, P. C. Abbott, \& M. R. Reed (Eds.), Competitiveness in international food markets (pp. 261-278). Boulder, Colorado: Westview Press.

Barichello, R. R. (1995). Overview of Canadian agricultural policy systems. In R. M. A. Loyns, R. D. Knutson, \& K. Meilke (Eds.), Understanding Canada/United States grain disputes: Proceedings of the first Canada/U.S. agricultural and food policy systems information workshop (pp. 37-59). Winnipeg, Minnesota: Friesen Printers.

Beesley, K. B., \& Ramsey, D. (2009). Agricultural land preservation. In International encyclopedia of human geography (pp. 65-69). Elsevier Press: Oxford. http://dx.doi.org/10.1016/B978-0080449104.00886-5

Benjamin, C. (2011). Canada's disappearing farmland. Canadian Dimension, 45(4), 27-29.

Blay-Palmer, A. (2012). Alternative land use services and the case for multifunctional policy in Canada. In R. MacRae \& E. Abergal (Eds.), Health and sustainability in the Canadian food system. Vancouver, British Columbia: UBC Press, pp. 39-69.

Bray, C. E. (1980). Agricultural land regulation in several Canadian provinces. Canadian Public Policy, 6(4), 591-604. http://dx.doi.org/10.2307/3549758

Bryant, C. R. (2011). Les dynamiques des agricultures périurbaines autour de Montréal: Défis et opportunités au service de la société métropolitaine. In Panorama des Régions du Québec, Édition 2011 (pp. 13-28). Québec: Institut de la Statistique du Québec.

Bryant, C. R. (2012). The social transformation of agriculture: The case of Québec. In J. R. Parkins \& M. G. Reed (Eds.), Social transformation in rural Canada: New insights into community, cultures and collective action (pp. 294-310). Vancouver, British Columbia: University of British Columbia Press.

Bryant, C. R., \& Granjon, D. (2007). Agricultural land protection in Québec: From provincial framework to local initiatives. In W. Caldwell, S. Hilts, \& B. Wilton (Eds.), Farmland preservation: Land for future generations (pp. 61-85). Guelph, Ontario: University of Guelph.

Bryant, C. R., Singh, B., \& André, P. (2007). The perception of risk to agriculture and climatic variability in Quebec: Implications for farmer adaptation to climatic variability and change. In E. Wall, B. Smit, \& J. Wandel (Eds.), Farming in a changing climate (pp. 157-170). Vancouver: University of British Columbia Press.

Bunce, M. (1998). Thirty years of farmland preservation in North America: Discourses and ideologies of a movement. Journal of Rural Studies, 14(2), 233-247. http://dx.doi.org/10.1016/S0743-0167(97)00035-1

Caldwell, W. (1995). Rural planning and agricultural land preservation: The experience of Huron County, Ontario. The Great Lakes Geographer, 2(2), 21-34.

Caldwell, W., Churchyard, A., Dodds-Weir, C., Eckert, A., \& Procter, K. (2011). Lot creation in Ontario's agricultural landscapes: Trends, impacts and policy implications. Report 3: Impacts and analysis. Retrieved from http://www.waynecaldwell.ca

Caldwell, W., \& Dodds-Weir, C. (2009). Canadian approaches to the preservation of farmland. Plan Canada, 49(2), 17-20.

Caldwell, W., \& Hilts, S. (2005). Farmland preservation: Innovative approaches in Ontario. Journal of Soil and Water Conservation, 60(3), 66A-69A.

Caldwell, W., Hilts, S., \& Wilton, B. (Eds.). (2007a). Farmland preservation: Land for future generations. Guelph, Ontario: University of Guelph.

Caldwell, W., Hilts, S., \& Wilton, B. (2007b). Farmland preservation in Ontario. In W. Caldwell, S. Hilts, \& B. Wilton (Eds.), Farmland preservation: Land for future generations (pp. 87-113). Guelph, Ontario: University of Guelph.

Canadian Federation of Agriculture [CFA]. (2010). Towards a national food strategy: A framework for securing the future of food. Retrieved from http://www.cfafca.ca/sites/default/files/NFS 0.pdf

Cavendish-Palmer, H. A. (2008). Planting strong boundaries: Urban growth, farmland preservation, and British Columbia's Agricultural Land Reserve. Master thesis (unpublished). Burnaby, British Columbia: Simon Fraser University. 
Connell, D. J. (2009). Planning and its orientation to the future. International Planning Studies, 14(1), 85-98. http://dx.doi.org/10.1080/13563470902741609

Connell, D. J. (2010). Schools of planning thought: Exploring differences through similarities. International Planning Studies, 15(4), 269-280. http://dx.doi.org/10.1080/13563475.2010.517286

Dakers, S. (1996). Agriculture: The policy agenda (Current Issue Review 93-9E). Ottawa: Minister of Supply and Services Canada.

Dakers, S., \& Forge, F. (2000). Agriculture: The policy agenda (Current Issue Review 93-9E, Revised). Ottawa: Government of Canada. Retrieved from http://dsp-psd.pwgsc.gc.ca/Collection-R/ LoPBdP/CIR/939-e.htm\#A.\%20Overview

Food Secure Canada. (2011). Resetting the table: A people's food policy for Canada. Retrieved from http://peoplesfoodpolicy.ca/files/pfpp-resetting2011-lowres 1.pdf

Forbes, J. D. (1985). Institutions and influence groups in Canadian farm and food policy (Monographs on Canadian Public Administration No. 10). Toronto: The Institute of Public Administration of Canada.

Friedmann, J. (2003). Why do planning theory? Planning Theory, 2(1), 7-10. http://dx.doi.org/10.1177/1473095203002001002

Furuseth, O. J., \& Pierce, J. T. (1982a). A comparative analysis of farmland preservation programmes in North America. Canadian Geographer, 26(3), 191206. http://dx.doi.org/10.1111/j.1541-0064.1982. tb01448.x

Furuseth, O. J., \& Pierce, J. T. (1982b). Agricultural land in an urban society. Washington, D.C.: Association of American Geographers.

Gayler, H. J. (2003). Agritourism developments in the rural-urban fringe: The challenges of land-use and policy planning in the Niagara region. In K. B. Beesley, H. Millward., B. Ilbery, \& L. Harrington (Eds.), The new countryside: Geographic perspectives on rural change (pp. 179-196). Brandon, Manitoba, and Halifax, Nova Scotia: Brandon University Rural Development Institute and St. Mary's University.

Gayler, H. J. (2004). The Niagara Fruit Belt: Planning conflicts in the preservation of a national resource. In M. B. Lapping \& O. J. Furuseth (Eds.), Big places, big plans (pp. 55-82). Aldershot, UK: Ashgate.

Gayler, H. J. (2005). Stemming the urban tide: Policy and attitudinal changes for saving the Canadian countryside. In A. Gilg, R. Yarwood, S. Essex, J. Smithers, \& R. Wilson (Eds.), Rural change and sustainability: Agriculture, the environment and communities (pp. 151-168). Wallingford, UK: CABI Publishing.

Gayler, H. J. (2010). Ontario's Greenbelt and places to grow legislation and the future for the countryside and the rural economy. In G. Halseth, S. Markey, \& D. Bruce, (Eds.), The next rural economies: Constructing rural place in global economies (pp. 75-88). Wallingford, UK: CABI Publishing.

Hiley, J. (2007). Opening gates, not reinforcing fences: Land use planning in Canada. In W. Caldwell, S. Hilts, \& B. Wilton (Eds.), Farmland preservation: Land for future generations (pp. 163-191). Guelph, Ontario: University of Guelph.

Hoffman, N. (2001). Urban consumption of agricultural land. Rural and Small Town Canada Analysis Bulletin (Catalogue No. 21-006-XIE), 3(2). Ottawa: Statistics Canada.

Howlett, M., Ramesh, M., \& Perl, A. (2009). Studying public policy: Policy cycles and policy subsystems. Don Mills, Ontario: Oxford University Press.

International Planning Committee for Food Sovereignty. (2002). Food sovereignty: A right for all - political statement. Retrieved from http://www.foodsovereignty.org/ Jochim, A. E., \& May, P. J. (2010). Beyond subsystems: Policy regimes and governance. Policy Studies Journal, 38(2), 303-327. http://dx.doi.org/10.1111/j.15410072.2010.00363.x

Johnston, T., \& Smit, B. (1985). An evaluation of the rationale for farmland preservation policy in Ontario. Land Use Policy, 2(3), 225-237. http://dx.doi.org/10.1016/0264-8377(85)90071-7

Leung, H. L. (2003). Land use planning made plain (Second ed.). Toronto: University of Toronto Press.

Miner, W. M. (1994). Assessing the competitiveness of the Canadian food sector. In M. E. Bredahl, P. C. Abbott, \& M. R. Reed (Eds.), Competitiveness in international food markets (pp. 261-278). Boulder, Colorado: Westview Press.

Moyer, W., \& Josling, T. (2002). Agricultural policy reform: Politics and process in the EU and US in the 1990s. Aldershot, UK: Ashgate Publishing.

National Farmers Union [NFU]. (2010). Losing our grip: How a corporate farmland buy-up, rising farm debt, and agribusiness financing of inputs threaten family farms and food sovereignty. Saskatoon, Saskatchewan: National Farmers Union. 
Qualman, D. (2011). The state of agriculture in Canada and the need for food sovereignty. In H. Wittman, A. A. Desmarais, \& N. Wiebe (Eds.), Food sovereignty in Canada: Creating just and sustainable food systems (pp. 20-42). Black Point, Nova Scotia: Fernwood Publishing.

Ritson, C., \& Harvey, D. R. (Eds.). (1997). The common agricultural policy (Second Ed.). Wallingford, UK: CAB International.

Simpson-Lewis, W., Moore, J. E., Pocock, N. J., Taylor, M. C., \& Swan, H. (1979). Canada's special resource lands: A national perspective of selected land uses (Map Folio No. 4). Ottawa: Lands Directorate, Environment Canada.

Skogstad, G. (1990). Canada: Conflicting domestic interests in the MTN. In G. Skogstad \& A. F. Cooper (Eds.), Agricultural Trade: Domestic Pressures and International Tensions (pp. 39-60). Halifax: The Institute for Research on Public Policy.

Skogstad, G. (2012). Affecting paradigm change in the Canadian agriculture and food sector. In R. MacRae $\&$ E. Abergal (Eds.), Health and sustainability in the Canadian food system (pp. 17-38). Vancouver: University of British Columbia Press.

Smith, B. (1998). Planning for agriculture: Resource materials. Burnaby, British Columbia: Provincial Agricultural Land Commission.

Smith, B. (2007). A work in progress: The British Columbia farmland preservation program. In W. Caldwell, S. Hilts, \& B. Wilton (Eds.), Farmland preservation: Land for future generations (pp. 115-162). Guelph, Ontario: University of Guelph.

Standing Committee on Agriculture and Agri-Food. (2010). Competitiveness of Canadian agriculture: Report of the standing committee on agriculture and agri-food.

Ottawa: Government of Canada.

Wiebe, N., \& Wipf, K. (2011). Why should Canada pursue food sovereignty? Nurturing food sovereignty in Canada. In H. Wittman, A. A. Desmarais, \& N. Wiebe (Eds.), Food sovereignty in Canada: Creating just and sustainable food systems (pp. 119). Black Point, Nova Scotia: Fernwood Publishing.

Wilson, B. K. (1990). Farming the system: How politicians and producers shape Canadian agricultural policy.

Saskatoon, Saskatchewan: Western Producer Prairie Books.

Wilton, B. (2007). Farmland preservation perspectives. In W. Caldwell, S. Hilts, \& B. Wilton (Eds.), Farmland preservation: Land for future generations (pp. 13-32). Guelph, Ontario: University of Guelph. Wittman, H., Desmarais, A. A., \& Wiebe, N. (Eds.). (2010). Food sovereignty: Reconnecting food, nature and community. Black Point, Nova Scotia: Fernwood Publishing and Food First Books.

Wittman, H., Desmarais, A. A., \& Wiebe, N. (Eds.). (2011). Food sovereignty in Canada: Creating just and sustainable food systems. Black Point, Nova Scotia: Fernwood Publishing. 